\title{
A Comparative Analysis of Residential Care: A Five-Country Multiple Case-Design Study
}

\author{
Sigrid James ${ }^{1}$ (I) - Lucas Wilczek ${ }^{1} \cdot$ Juri Kilian $^{1} \cdot$ Eeva Timonen-Kallio $^{2} \cdot$ Amaia Bravo $^{3}$. \\ Jorge F. del Valle ${ }^{3}$. Laura Formenti ${ }^{4}$. Alina Petrauskiene ${ }^{5}$. Jolanta Pivoriene ${ }^{5}$. \\ Alessandra Rigamonti ${ }^{4}$
}

Accepted: 19 November 2021 / Published online: 13 December 2021

(C) The Author(s) 2021

\begin{abstract}
Background Despite a global policy push toward the advancement of family- and community-based care, residential care for children and youth remains a relevant and highly utilized out-of-home care option in many countries, fulfilling functions of care and accommodation as well as education and treatment.

Objective As part of a larger project involving five European countries (Finland, Germany, Italy, Lithuania, and Spain), the objective was "to map" the context and content of residential care in each country, thereby building a foundation for meaningful comparisons and deepened understanding of each system's inherent logic. Within the context of global deinstitutionalization efforts, the study also aimed to understand factors that hinder or enhance the transformation of residential care.

Method Using an embedded multiple-case design, data was gathered by each country on its residential care macro context as well as salient variables related to three units of analysis-residential care system/program features, residential care training and personnel, characteristics of youth. Cross-case synthesis was used to summarize and compare cases across relevant dimensions.

Results The analysis highlighted areas of overlap and singularity, particularly with regard to utilization rates, concepts and methods, workforce professionalization, and characteristics of youth.

Conclusions Findings provide a more nuanced understanding of how residential care continues to be viewed and utilized in some countries, challenging the 'residential-care-as-alast-resort-only' rhetoric that is currently dominating the discourse on residential care. It further provides an understanding of historical and sociocultural factors that need to be considered when trying to transform services for children, youth, and their families.
\end{abstract}

Keywords Residential care for children and youth · Foster care - Child welfare . Deinstitutionalization · Out-of-home care · Group care · International child welfare · Childwelfare policy

Sigrid James

sigrid.james@uni-kassel.de

Extended author information available on the last page of the article 


\section{Introduction}

In its long history, residential care ${ }^{1}$ has fulfilled an important function in child-serving systems to address the needs of children and youth who for various reasons cannot remain with their families. As a type of live-in out-of-home placement, it offers care and services for multiple children under the supervision of trained staff (Child Welfare Information Gateway, n.d.). While still a part of the spectrum of services available for children and youth, serious concerns have been raised about residential care over the last few decades. Abuse scandals, occurring in residential care programs across many countries, point to the potential for exploitation and maltreatment in such settings. There is also evidence of an increased risk of developmental delays as well as adverse outcomes in some areas of psychosocial functioning, particularly among careleavers (e.g., Cameron et al., 2018; Gutterswijk et al., 2020; Ijzendoorn et al., 2020). In addition, high cost, a comparatively weak evidence base for effectiveness, an unstable and inadequately trained workforce, and a lack of involvement of the family of origin pose serious challenges for residential care programs (James, 2015; Moore et al., 2018).

Taken together, these concerns form the basis for global deinstitutionalization efforts, aimed at reducing the use of residential care while spurring on the development of family-based care options (e.g., Goldman et al., 2020). In some-primarily Anglophone-countries, child welfare policies increasingly mandate the use of family- or community-based interventions over residential care (e.g., Chadwick Center \& Chapin Hall, 2016; Dozier et al., 2014). While such efforts have succeeded in reducing residential care utilization rates in a number of countries (e.g., Ainsworth \& Thoburn, 2014; Lee, 2020), they have also produced unintended effects. They have inadvertently raised the clinical severity of youth placed in residential care (e.g., Duppong Hurley et al., 2009) and increased the risk of relocation away from the communities of the youth (e.g., Berman et al., 2009). Lastly, a lowering of standards for family foster care has been noted in order to overcome gaps in available placements, which emerged because of residential care program closures (e.g., Ainsworth \& Hansen, 2005).

Yet despite the focused policy push toward the advancement of family- and communitybased care, residential care remains a relevant and highly utilized setting in many countries, fulfilling functions of care and accommodation as well as education and treatment (Ainsworth \& Thoburn, 2014; Islam \& Fulcher, 2018). While many youths are placed in residential care programs temporarily or during times of transition, some still spend years in programs that range from small group homes to large institutions (Huynh et al., 2019; Ijzendoorn et al., 2020). How residential care is used and what function it plays in child welfare systems can be attributed to a range of factors. Among them are sociocultural and historical developments, available resources for child welfare, cultural notions about family, a lack of family-based placement alternatives as well as a belief that residential care can be beneficial to children (e.g., Ezell et al., 2011; Timonen-Kallio \& Hämäläinen, 2019). Some experts argue that residential care, in the form of small group homes and therapeutically focused programs, needs to remain an integral part of a comprehensive continuum of services for children and adolescents with varied needs (Holmes et al., 2018; Whittaker

\footnotetext{
1 In this paper, we use the generic term "residential care" to encompass out-of-home group-based programs for children and youth. These programs may be of different sizes, serve different functions, or target diverse problems. As others have pointed out (Lee \& Barth, 2011) and as this paper will confirm, terminology remains a critical issue in the field of residential care.
} 
et al., 2016). They propose that instead of focusing on downsizing residential care, efforts should be directed at improving the quality of care within residential programs (Daly et al., 2018; Farmer et al., 2017; Huyhn et al., 2019).

The current paper is the first in a three-year project on residential care involving five European countries. ${ }^{2}$ The project's overall aim is to strengthen the quality of residential programs in child welfare systems by enhancing the training of residential care workers in core competency areas. In a first project phase, data was gathered "to map" the context and content of residential care in each involved country. This effort was guided by three research questions: (1) How similar or different is residential care in its programming and features across the five countries? (2) How does the training of residential care workers differ? (3) How do the characteristics of children and youth in residential care programs compare? Findings aim, first of all, to guide the development of subsequent phases of the project. Moreover, however, they are expected to create a foundation for meaningful comparisons and deepened understanding of each system's inherent logic. Within the context of global deinstitutionalization efforts, they will provide insight into the objectives and challenges of child welfare systems as they deliver residential care services and identify factors that may hinder or enhance the reduction or transformation of residential care.

\section{Method}

\section{Ethics Statement and Conflict of Interest}

This study did not involve human subjects and did not require an ethics review. No conflicts of interest are reported by any of the authors.

\section{The Case Study Design}

Yin (2018) describes the case study as "an empirical method that investigates a contemporary phenomenon (the 'case') in depth and within its real-world context, especially when the boundaries between the phenomenon and the context may not be clearly evident" ( $p$. 15). Case studies are always contextually embedded and characterized by a "proximity to reality" (Flyvbjerg, 2006, p. 236). They are ideal for gaining a deep and detailed understanding of a "case" or "bounded system," which can range from individual persons to large organizational systems (Creswell, 2017). In case study investigations, data can be drawn from multiple sources; they may involve qualitative as well as quantitative data, and have exploratory, descriptive, or explanatory objectives. The unit of analysis may be focused on one or more cases (Gustafsson, 2017). Single- and multiple-case designs can be further differentiated, depending on their unit of analysis, as either holistic (involving a single unit) or embedded (involving multiple units of analysis) (Yin, 2018). Generally, a multiple-case design is preferred over a single-case design because it offers contrast and is thus considered to be more robust (Heale \& Twycross, 2018).

\footnotetext{
${ }^{2}$ Blinded the Erasmus + project entitled "Empowering Residential Child Care through Interprofessional Training" is a three-year project (2018-2021), which involved experts from five universities in five European countries (https://ercci.turkuamk.fi/).
} 


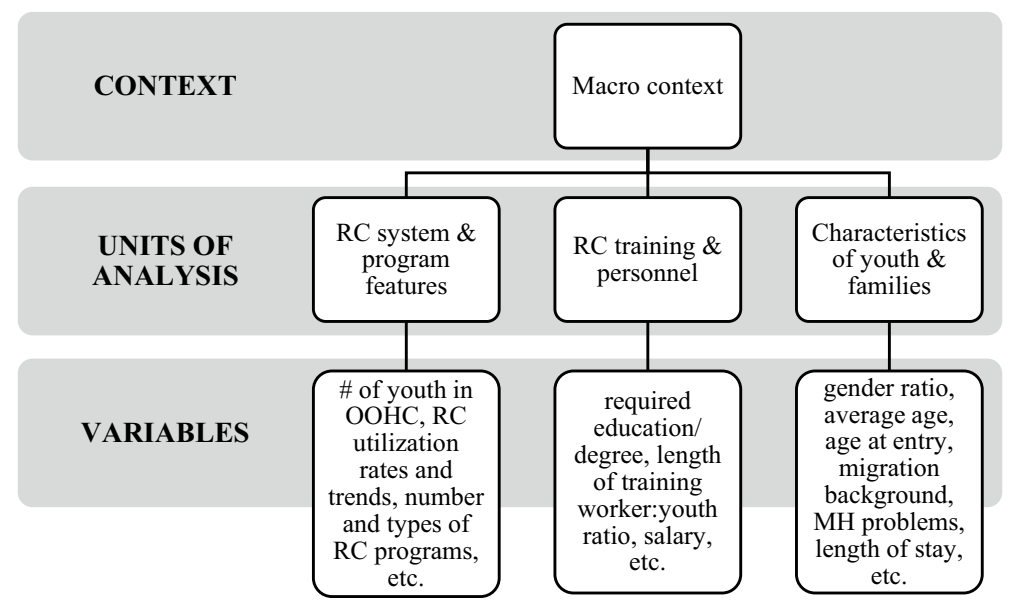

Fig. 1 Conceptual framework for multiple-case design

Case studies have inherent limitations related to epistemological concerns about scientific validation and the confirmability of findings. Difficulties in analyzing and presenting large volumes of data constitute an additional challenge. This is particularly true when multiple cases are involved. Analysis at a theory-generating level is also more complex when multiple cases are considered. Yet evidence from more than one case has the potential to produce theory that is more grounded and convincing. Despite these limitations, case studies remain an integral part of the methodological toolbox of researchers in various fields (Gustafsson, 2017; Yin, 2018).

\section{Design and Research Questions}

The current analysis uses an embedded multiple-case design, whereby each country with its residential care system constitutes a case $(n=5)$. Within this design, each case is understood as embedded in context and along different units of analysis (see Fig. 1 for the conceptual map of the study). The five cases - Finland, Germany, Italy, Lithuania and Spain - were carefully chosen a priori to represent countries from different geographic regions and social welfare systems in Europe. The choice of countries also depended on logistical reasons such as the availability of interested researchers with requisite expertise in residential care. Three research questions pertaining to residential care programming and features, the training of residential care workers, and the characteristics of children and youth in residential care programs (see specific questions in the introduction of the paper) guided data collection and analysis and reflect the nested conceptual understanding of residential care.

\section{Context}

Context describes the macro environment of residential care. It encompasses salient cultural and socioeconomic factors as well as historic developments and policies believed to have shaped child welfare and residential care in each country. To capture the current child welfare context, the number of children in out-of-home care and/or rate per 1,000 minors 
were also included. Whether and how these contextual factors (directly or indirectly) impact a "case," cannot always be clearly determined beforehand (Yin, 2018).

\section{Units of Analysis}

Major analytic categories were identified a priori based in part on the broad aims of the research project. They were conceptualized in a nested way from organizational characteristics to youth level characteristics and included: (1) residential care system and program features; (2) residential care training and personnel; and (3) characteristics of children and youth. Research questions explicated in the introduction of the paper capture these domains.

\section{Variables}

Within each analytic category, variables were first identified deductively based on prior knowledge of residential care programs and child welfare systems. Additional units of analysis that seemed to have relevance for describing and understanding residential care in each country were subsequently added throughout the data collection process. Variables of interest for this analysis are listed below.

- Residential care system/program features: utilization trends; percentage of children in residential care vs. foster care; number and types of residential care programs; agency type (public/private); average number of children per program; primary conceptual models; parent/family services; careleaver services; national or regional quality standards; (base) rate per day/funding; major current issues; perceived deficits and strengths.

- Residential care training and personnel: required education/degree; length of training/ studies; curriculum content on residential care; worker-youth ratio; salary in relation to national median.

- Characteristics of children and youth in residential care: gender; age; percentage of youth with migration background; primary reasons for entry into residential care; average length of stay; rate of mental health problems; percentage of single parent families and/or other risk factors.

\section{Procedures}

The first author and her team were tasked with guiding the conceptualization and procedures for this part of the project. A matrix with the a priori analytic categories and variables was developed and distributed to each team for data collection. Additional relevant domains were added during a participatory process as part of a training week, during which all teams were present. Upon returning to the respective countries, each team gathered data from a range of available sources in the summer of 2019, including government reports, research studies, administrative data, and relevant websites. During this process, a few categories and/or variables were deepened or were merged. 


\section{Analysis}

The analysis of case study data is not well specified, and researchers have relative freedom to develop their analytic strategy (Lee et al., 2010). In multiple-case design studies, the basic goal is to search for patterns by making comparisons within and between cases (Gustafsson, 2017). This process can be started by creating a matrix of contrasting categories. Cross-case synthesis aims "to retain the integrity of the entire case and then to compare or synthesize any within-case patterns across the cases" (Yin, 2018, p. 196). Challenges in the data collection and analysis process included differences in terminology across countries, the use of different denominators and time-points when reporting available statistics as well as missing data. Whenever possible, the attempt was made to standardize, i.e., to use the same denominator when reporting statistics. In cases of missing data, extra efforts were made in a second round of data collection to unearth the information.

\section{Results}

Due to the extent of the data collected, results are presented in highly synthesized form and will focus on variables deemed to be of particular interest to discussions on residential care. With regard to within-case synthesis, relevant information on the macro context of child welfare as well as the units of analysis will first be summarized for each country. Primary current issues and challenges as well as perceived strengths and deficits of each system are briefly outlined at the end of each case description. Most data are reported for the years 2016-2018 unless otherwise indicated. Subsequently, areas of particular interest or divergence will be highlighted in a final comparative analysis across cases (see Table 1 for an overview of salient variables).

\section{Finland}

\section{Relevant Macro Context}

In Finland, the Child Welfare Act of 2007 reflected changes toward a more child-centered approach, characterized by preventive and family-oriented services rather than a child protection perspective (Forsberg \& Kröger, 2010). The current approach can be described as educative, which implies aiming to work cooperatively in partnerships with families toward the best interest of the child. "Taking a child into care is seen as an intervention of last resort and, if necessary, it should be for as short a time as possible" (Francis et al., 2007, p. 340). The basic principle of Finland's Child Welfare Act is as follows: If it becomes necessary to intervene in a family's affairs, it should be in the mildest and least intrusive form possible. Efforts are made to help in such a way that children can remain at home. Despite the strong prevention focus, the out-of-home care rate stands at 10 per 1000 children. This comparatively high rate is attributed to the use of voluntary "open care" placements but also to the increasing severity of psychosocial problems faced by families, which in many instances necessitates out-of-home care placement. 


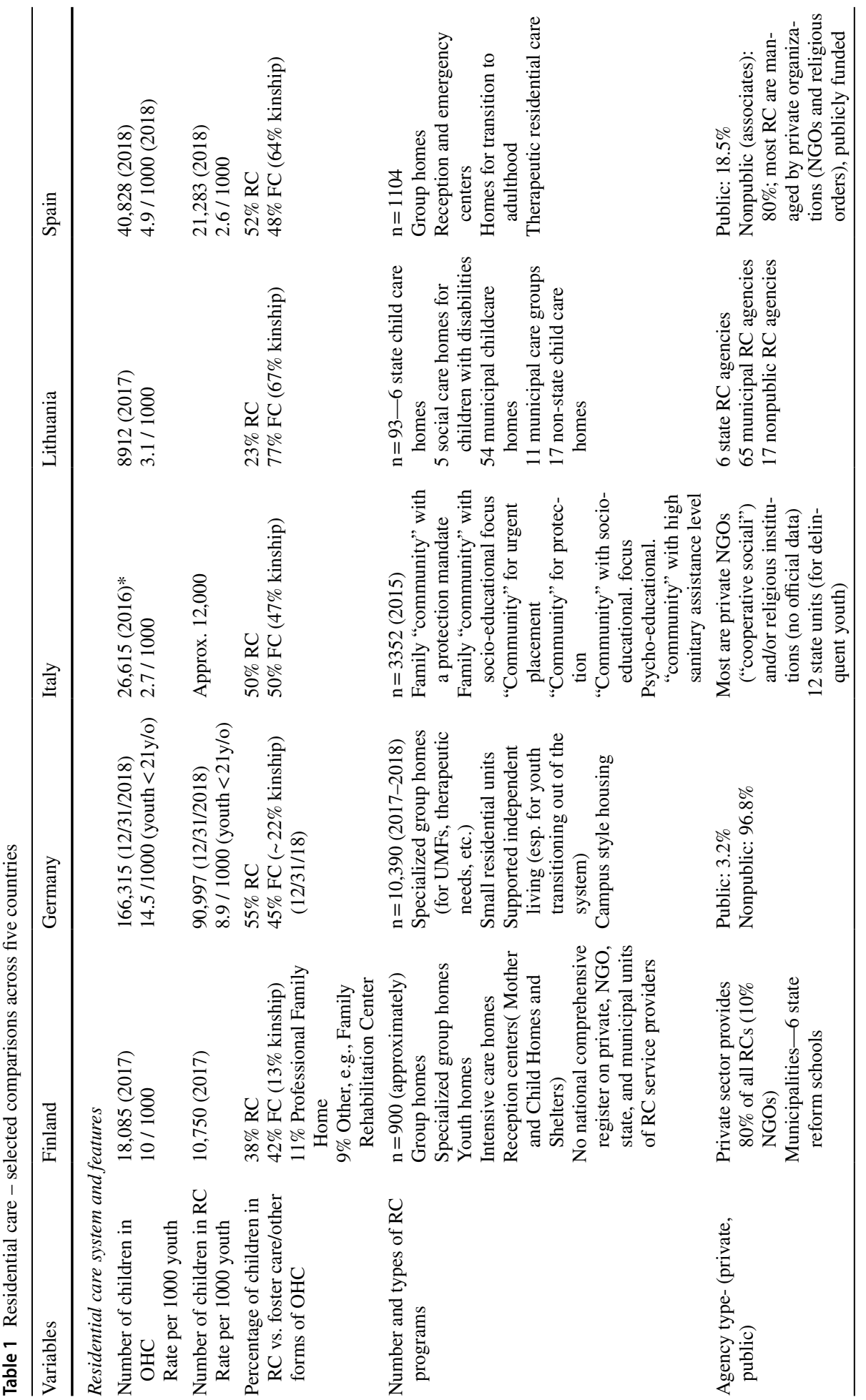




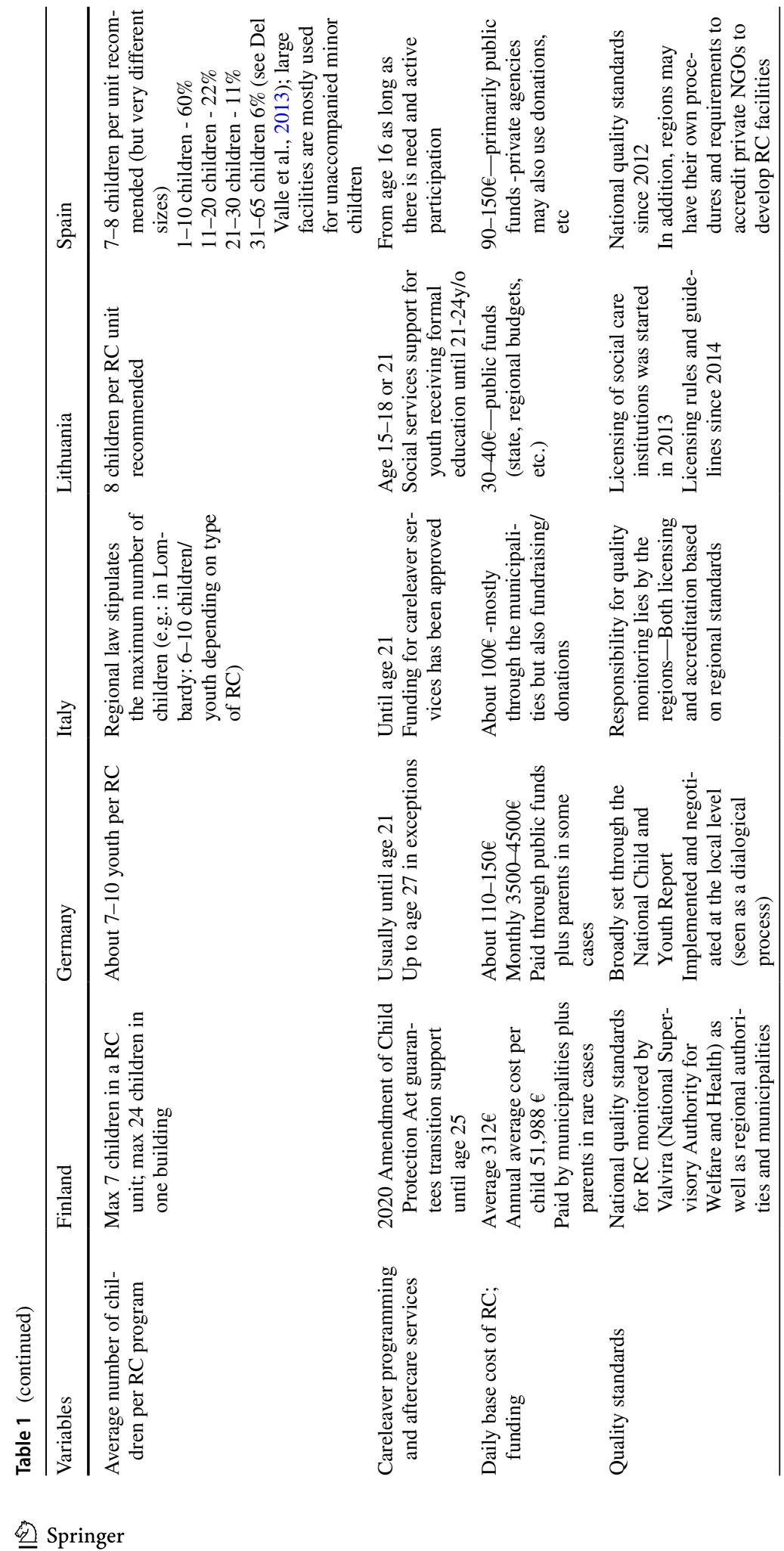




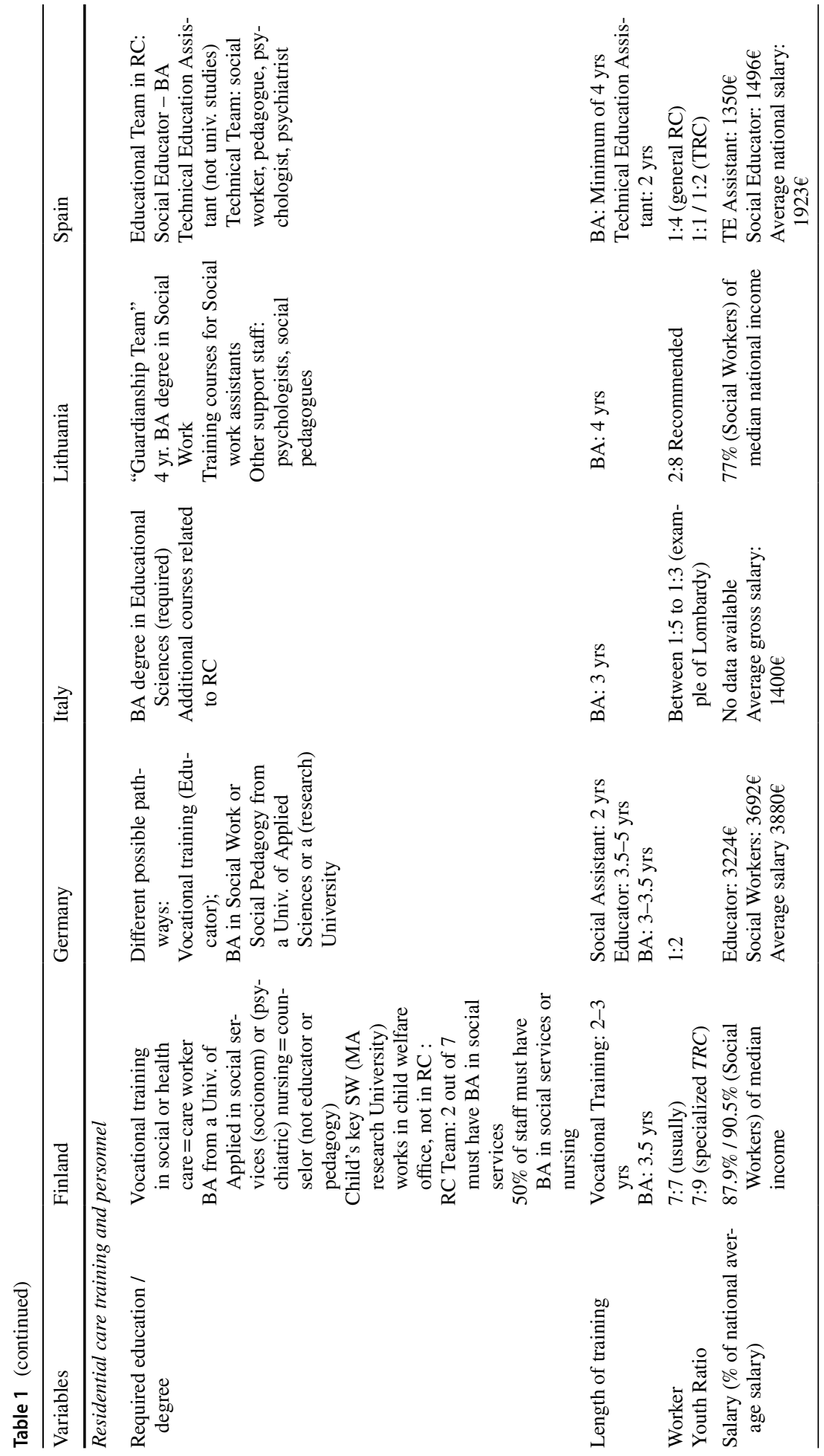




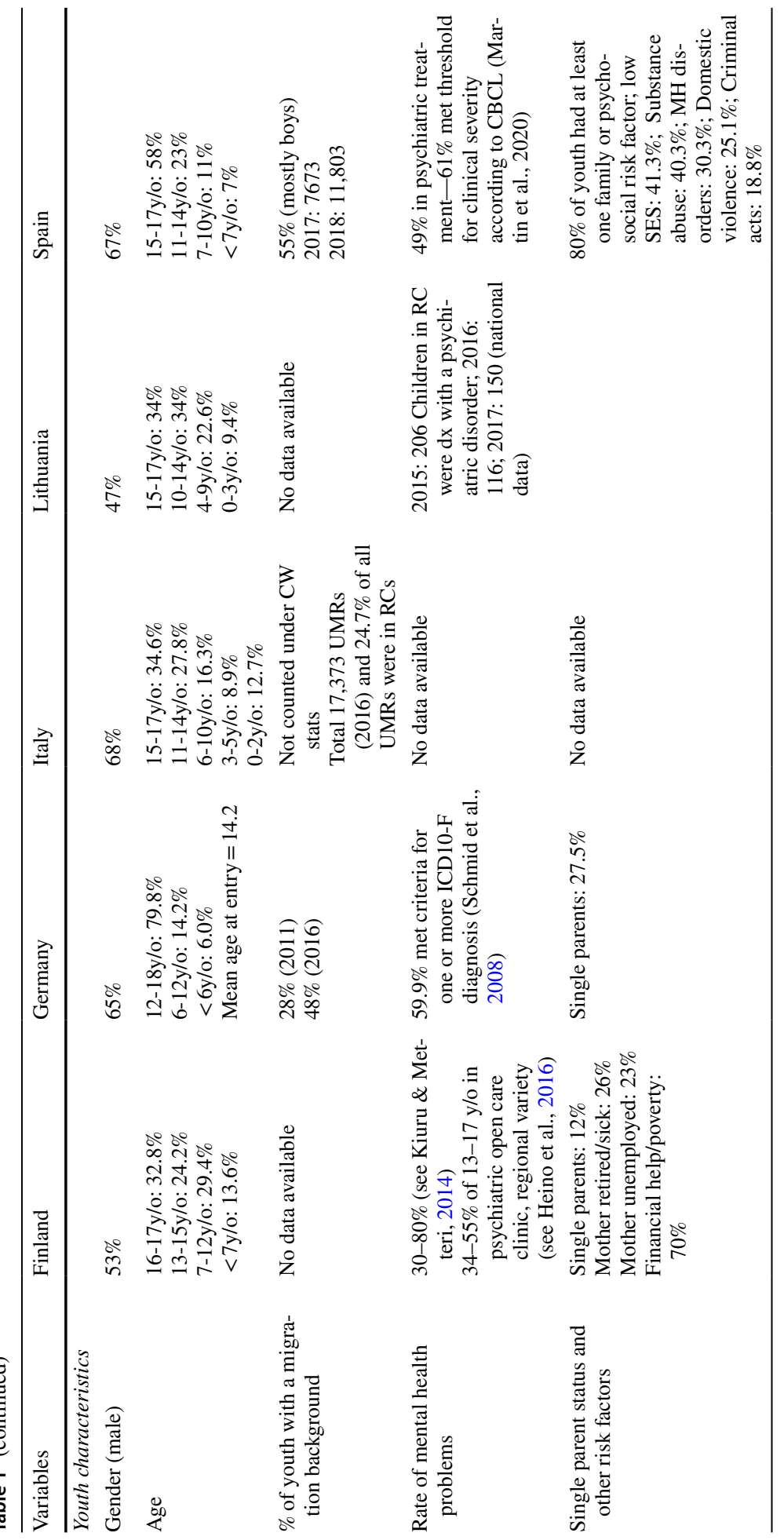




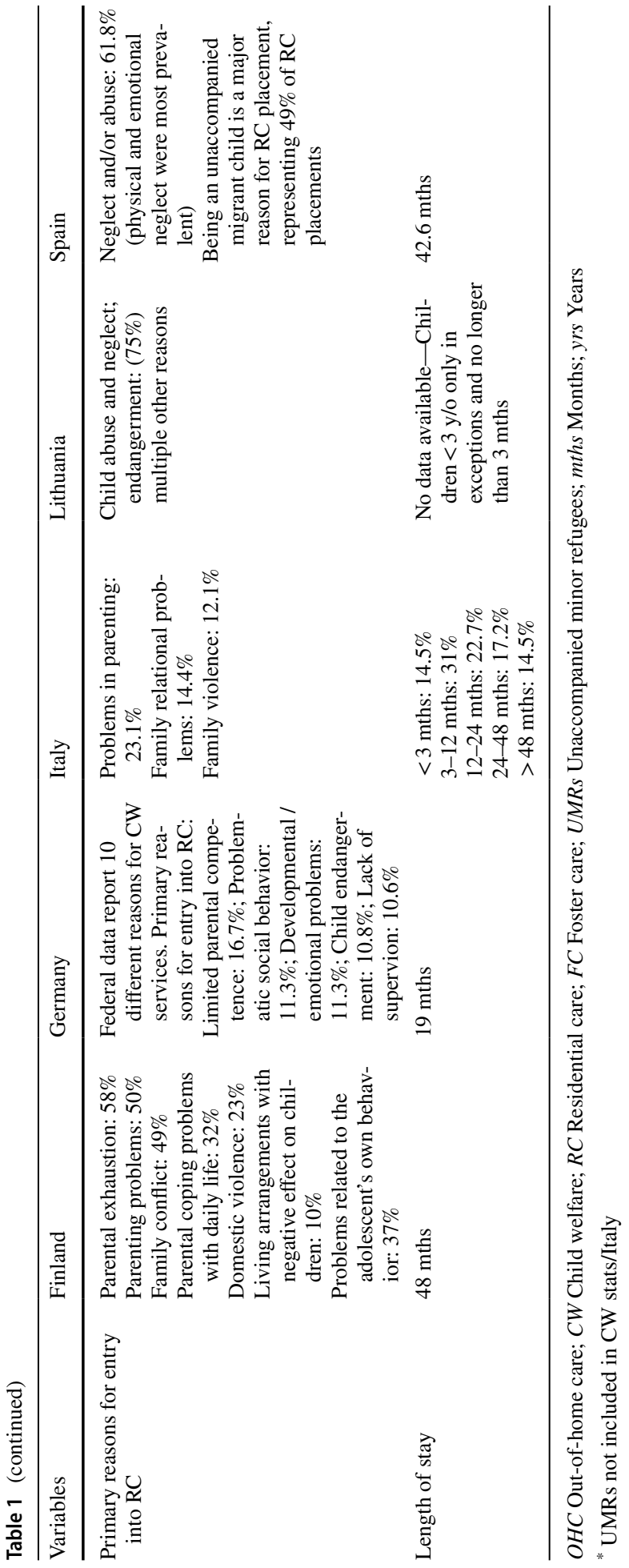




\section{Residential Care System/Program Features}

Residential care was long favored over foster care but this has shifted since an amendment of major child welfare legislation was passed in 2012, which introduced initiatives to strengthen foster care (Hoikkala \& Kemppainen, 2015). The percentage of family-based foster care options (nonrelative, relative, professional, rehabilitative) has grown since then and now far exceeds that of residential care (62\% versus $38 \%)$. Kinship care makes up $13 \%$ of foster care. Timonen-Kallio and colleagues (2017) describe today's residential care as a mix of programs administered by municipalities, by the state (in the form of reform schools), through voluntary and independent associations, and increasingly, through the private sector. The latter two account for over $90 \%$ of residential care programs with 671 units encompassing small group homes for children or adolescents to a range of specialized programs for youth (Porko, Heino, \& Eriksson, 2018). Yet various terms used for residential care (e.g., group home, specialized group home, youth home, intensive care home, reception center) do not necessarily describe the nature of a program, how it operates, what its goals are, or even how large it is (Laakso, 2009; Porko et al., 2018). Policy specifies that no more than seven children or youth can be placed in a residential care unit with a maximum of 24 per facility. Placement into residential care is primarily related to significant challenges in coping with everyday life, inadequate parenting skills as well as conflicts in parenting and family life, which are often associated with parental substance abuse and/ or mental health problems. However, the youth's own behavior increasingly is a precursor for placement (Heino, Hyry, Ikäheimo, Kuronen, \& Rajala, 2016; Kananoja \& Ruuskanen, 2019). In 2017, 15\% more children were being placed into emergency care than in 2016 (Puustinen-Korhonen, 2018).

The primary practice approach in Finland's residential care programs can be described as milieu-based and relationship-focused. It emphasizes a home-like, safe and nurturing environment in small units that fosters stable relationships with adults (Laakso, 2009; Timonen-Kallio et al., 2017) and positive interactions between youth, peers and adults (Lahtinen \& Pekkarinen, 2020). While no child welfare data on migration background are collected, policy stipulates that the child's linguistic, cultural and religious background must be taken into account in child welfare decision-making and practice approaches (Child Welfare Act 417/2007, 4§). Reunification with the biological family is the central goal of any out-of-home care placement, and current law mandates active involvement of a youth's family in residential care services. The child's main residential care worker is expected to contact a youth's parents every week. Furthermore, services for youth in child welfare are guaranteed until the age of 25, according to recent legislation (Working Group to Reform After-Care, 2019).

National quality standards regulate child welfare practice, including residential care programs (Malja, Puustinen-Korhonen, Petrelius, \& Eriksson, 2020). These are strictly monitored by local authorities and the National Supervisory Authority Valvira. However, there is great variability in the implementation of these standards (Forsell, 2019; Porko et al., 2018).

\section{Residential Care Training and Personnel}

The work of a social welfare professional in residential care encompasses case management, counseling and care activities. These complementary competencies are addressed through teams, which consist of youth counselors with university degrees in social services 
or health care (three-and-a-half years of studies) or integrated residential practice nurses (two to three years of vocational training). Half of a team must hold a bachelor's degree in social services or health care. University training in areas of child welfare is based on generalist content and specialization courses in residential care are not offered, instead additional training may be provided by the employer. In residential care programs, the worker to youth ratio is 'one-on-one' (7:7) or even better (9:7) in specialized settings (Valvira, 2012). Residential care workers earn close to $90 \%$ of the national median salary.

\section{Characteristics of Children and Youth in Residential Care}

Slightly more than half of the youth in residential care are male. About $57 \%$ are adolescents, $29.4 \%$ are between seven to twelve years old and another $13.6 \%$ are younger than seven. The Child Welfare Act (417/2007) does not contain any age-specific criteria for child custody. However, infants $(<1$ year) are taken into care less in Finland than in other Nordic countries (Hestbæk et al., 2020). The average stay in Finnish residential care is 48 months. Given the explicit aim of returning children quickly to their families, it is assumed that the severity of children in residential care may be higher when they finally enter care and that other preventive options may have been exhausted, making it harder for these children to return to their families or be placed in foster care (Heino et al., 2016). The rate of mental health problems among residential care youth ranges between 30-80\% depending on research design and sample (Kiuru \& Metteri, 2014). About $12 \%$ of youth come from single parent families and $70 \%$ are from families living in poverty. The younger the child at age of entry into care, the more disadvantaged the family tends to be (Heino et al., 2016).

\section{Major Current Issues, Strengths and Deficits}

The privatization of residential care programs has been identified as a particular challenge for Finnish residential care, leading to a competitive environment with insufficient quality monitoring (Porko et al., 2018). It is further unclear how effective preventive services actually are in preventing out-of-home placement. The number of emergency placements of teenagers has grown significantly in recent years (Kuoppala, Forsell, \& Säkkinen, 2019) as has the number of involuntary child welfare services (Porko et al., 2018). To improve integration of all elements of the child welfare system, updated guidelines were published in 2019 (Malja et al., 2020). Other challenges include a lack of qualified residential care personnel and high staff turnover. The workload is demanding and stressful. Social workers who are responsible for managing children's cases note that in $40 \%$ of the cases they would have required more time to do their work properly (Heino et al., 2016; Kananoja \& Ruuskanen, 2019). While professionalism among residential care workers has been strengthened in recent years, increased professionalization does not automatically translate into better outcomes for children. Thus, more detailed requirements and standards for staff training and optimal staff-youth ratio are expected (Porko et al., 2018). 


\section{Germany}

\section{Relevant Macro Context}

Residential care has a long and rich history in Germany, dating back to the sixteenth century. There are many notable milestones in the evolution of residential care (e.g., the pedagogy of Pestalozzi, Home Mission movement, the residential care campaign of the 1960s), and debates about the value of residential versus family-based care have been ongoing for centuries (Günder \& Nowacki, 2020). Institutionalized forms of care dominated the period after World War II-particularly in the former East Germany - and were often tied to repressive and even abusive practices. This prompted major reforms in residential care, specifically, and child welfare more generally, culminating in the passage of new child welfare legislation in 1991 [Kinder- und Jugendhilfegesetz] and subsequent amendments. While also strengthening the rights of parents, greater emphasis was placed on child wellbeing and child protection. Residential care 'diversified' and smaller group home options emerged, accompanied by efforts to decentralize, deinstitutionalize, individualize and professionalize residential care while supporting a participatory approach that would strengthen the rights of children and their parents (Janze \& Pothmann, 2003; Zukunftsforum Heimerziehung, 2021). Altogether, rates of out-of-home care - counting foster care and residential care - are comparatively high at 14.5 per 1000 children younger than 21 (Statistisches Bundesamt, 2018).

\section{Residential Care System/Program Features}

Residential care in its current diverse forms remains a primary form of intervention in Germany's child welfare system. At the end of 2018, a total of 90,997 children and youth were reported to be in residential care (Statistisches Bundesamt, 2018). Numbers had been steadily increasing in recent years, which was mainly attributed to rising numbers of unaccompanied minor refugees entering residential care programs (AKJ, 2018); currently, however, this trend seems to have been reversing. The utilization ratio for residential versus foster care is favoring the former (55\% versus $45 \%)$. As stated, residential care programs are mostly small (seven to ten youth on average) community-based group homes and supported living units with some homes offering specialized services. Over $95 \%$ of residential care programs are run by non-public organizations. Residential care is guided by pedagogical rather than therapeutic concepts, emphasizing learning through a milieu-based and "lifespace"-oriented [Lebenswelt] perspective, which stresses an individualized, participatory and relationship-based approach (Grietens, 2015). Increasingly, trauma-informed concepts are being introduced in residential care programs to meet the needs of youth with trauma (e.g., Gahleitner, 2012). So called "protection concepts" have also been developed and widely implemented in recent years following reports and research on sexualized violence (Kappler, Hornfeck, Pooch, Kindler, \& Tremel, 2019). "Parent work" [Elternarbeit] and parent participation are required per policy, but the operationalization and implementation vary greatly (Krause, 2019). Careleaver services have received growing attention during the past decade. About two-thirds of youth in out-of-home care leave the child welfare system before the age of 18. Per law services can be received until the age of 21 and, if indicated, even until 27 (Cameron et al., 2018). Standards for the entire child and youth welfare sector, including residential care, are set through the National Report for Children and Youth published through the Ministry of Families, Senior, Women and Youth every four 
years (BMFSFJ, 2020), yet each local child welfare system is tasked to come to an agreement with respective (residential care) programs and agencies about the content, scope, and quality of services to be provided. In this context, quality is understood as the product of a dialogical process shaped by the perspectives of all stakeholders (Merchel, 2020).

\section{Residential Care Training and Personnel}

In 2018, 77,118 care workers were employed in residential care (Statistisches Bundesamt, 2018). About $70 \%$ hold a three-and-a-half to five-year vocational degree as educators or, in fewer cases, have a two-year training as social assistants. About $30 \%$ hold bachelor's degrees in social work or social pedagogy, which are primarily attained in universities of applied sciences and are counted as the "professional workforce" in residential care. As a rule, neither group receives specialized training in residential care. About 57\% of residential care workers were working full-time in 2018 (Statistisches Bundesamt, 2018). The worker to youth ratio varies slightly in the German Federal State system. The state of Hessia, for example, has a set a ratio of about one to two (Landesjugendhilfeausschuss Hessen, 2014). Social educators earn less than social workers or social pedagogues and all lie somewhat below the average national gross income, depending on region and years of experience (Die Zeit, n.d.).

\section{Characteristics of Children and Youth in Residential Care}

Data on youth leaving residential care in 2016 report the following parameters (BGW, 2018; Fendrich et al., 2018): Two-thirds of the youth are male and the percentage of boys in residential care has gone up since 2011. Youth, age 12-18 years old, make up almost $80 \%$ of the residential care population. About 14\% range in age from 12 to 18 and another $6 \%$ are younger than six years old. ${ }^{3}$ The number of youths with at least one parent with a migration background lies at $48 \%$ and has gone up by about $20 \%$ since 2011 . Based on 2016 residential care data, the percentage of youth from families, in which German was not spoken, stood at $54 \%$ and about $28 \%$ came from single parent families. Youth enter residential care primarily due to lack of parental supervision, followed by parental incapacity. In $11 \%$ of the cases, child endangerment is the cited reason. Youth spend an average of 19 months in residential care. Regarding the prevalence of mental health problems, Schmid et al. (2008) determined that $59.9 \%$ of youth in residential care met ICD-10 diagnostic criteria, with a predominance of externalizing disorders.

\section{Major Current Issues, Strengths and Deficits}

Germany's child welfare system prides itself in a well-trained and professionalized workforce and its pedagogical concepts. Deinstitutionalization efforts have been largely successful and are evidenced by the broad array of available community-based group homes and residential programs. Preventive services as well as participatory and democratic decisionmaking processes, which also include independent complaint mechanisms, are emphasized

\footnotetext{
3 Official residential care statistics include the age group of 18- to 27-year-olds. These were excluded for the sake of comparison. However, if included the age breakdown is as follows: $<6: 3.8 \%$; 6-12 y/o: $9.0 \%$; 12-18y/o: 50.5\%; 18-27y/o: 36.7\% (BWG, 2018).
} 
(BMFSFJ, 2020; Heimerziehung, 2021). Many German residential care organizations are becoming aware of the needs of careleavers, and growing attention is paid to the development of aftercare services. Recently passed reforms of the German Child and Youth Care Law have taken those needs into consideration and have further strengthened provisions for aftercare support services.

The arrival of many unaccompanied minor refugees (UMRs) in 2015/2016 posed a particular challenge to Germany's residential care programs. While the number of UMRs has been decreasing, prompting closures of specialized programs for this group, addressing the needs of these youth remains a challenge. Other challenges involve children and youth with complex needs and family situations, for whom available programs do not seem to work, as well as the improvement of parental participation. Additionally, staff turnover is frequent, outcome data is lacking, and prevailing concepts and methods remain largely untested (Harder et al., 2013).

\section{Italy}

\section{Relevant Macro Context}

Institutional care dominated child welfare services in Italy until the 1970s. Services were centralized and mostly administered by church-affiliated institutions. First efforts toward deinstitutionalization commenced in the late 1960s and culminated in the passage of law 149/2001, which imposed the total closure of institutions by 2006 and designated residential care as an intervention of last resort after other placement options have been exhausted or in cases where family-based care is not available (Ducci, 2003).

Several laws have been passed during the past fifty years that have gradually transferred the administration and delivery of child welfare services from the state to regional and local authorities, resulting in great regional variability in the regulation and organization of services (Carrà, 2014; Del Valle et al., 2013). These efforts have also included an advancement of community-based alternatives (Canali \& Vecchiato, 2013; Canali, Maurizio, \& Vecchiato, 2016). Yet despite legislation and national campaigns to promote family foster care, cultural attitudes on the sanctity of the family and noninterference of the state when it comes to family matters have in part prevented greater acceptance of foster care. Instead, residential care is often preferred to foster care since it seemingly avoids the establishment of new affective bonds outside the family. Given negative cultural attitudes toward child welfare interference and services and the emphasis on the rights of the family, it is not surprising that Italy has a comparatively low rate of children in out-of-home care -2.7 per 1000 (Licursi et al., 2013).

\section{Residential Care System/Program Features}

The ratio between residential care and forms of foster care is relatively even according to current statistics but only because kinship care makes up a significant portion of family-based foster care (Corradini, 2017). The 2001 law that prompted the closure of large institutions also furthered the establishment of small family-style residential "care communities." In 2016, there were over 3,800 such communities serving children and youth with different needs. These include programs with a protection focus, socio-educational programs, child-parent units as well as therapeutic programs with a mental health focus 
(Palareti et al., 2012). Most residential care programs fall in the category of private NGOs and/or religious institutions; there are twelve state programs designed specifically for delinquent youth.

Regional law stipulates the maximum number of children to be placed in a residential care unit, which, for instance, in the state of Lombardy in Northern Italy includes 10 children in socio-educational programs and a maximum of six in a family-like community setting. National guidelines (MLPS, 2017a) recommend a limited number of children in programs to ensure a family-like atmosphere. Residential programs are primarily guided by pedagogical concepts, focused on creating a milieu that fosters community life and encourages the development of social competencies. Therapeutic change occurs by living together, following rules, sharing, demonstrating a capacity of adaption and active participation to the community life (Formenti \& Rigamonti, 2020). More recently, some units have begun to use the principles of behavioral psychology, attachment theory, trauma-oriented care as well as a participatory orientation.

Services for parents or families are recommended in current guidelines but are often not sufficiently implemented. Careleavers may receive services until age 21 , depending on the local availability of financial and organizational resources, and can receive support for semi-independent living (work, vocational training, housing) if indicated. Quality monitoring of programs is the responsibility of the regions, and on-site inspections take place when a program is established and subsequently each year.

\section{Residential Care Training and Personnel}

Since 2018, residential care workers need to hold a three-year bachelor's degree in educational sciences. No other training or specialized qualifications are required but continuing education and supervision are mandatory in many regions, and a master program on residential care was established at Milano Bicocca University in 2020. The worker to youth ratio is generally one to three or one to five.

\section{Characteristics of Children and Youth in Residential Care}

Male children and youth are overrepresented in residential care, counting for $68 \%$ of the residential care population. As in many countries, the majority of youths in residential care are in their teen years (close to two-thirds are between 11 to 17 years old). However, slightly more than one-third are ten or younger with $12.7 \%$ reported to be younger than two years old. Youth enter residential care for a range of reasons related to problems in parenting, relational problems as well as family violence. Stays in residential care are supposed to last no longer than 24 months, yet more than $30 \%$ of youth remain in programs more than two years, with about $14.5 \%$ staying longer than four years. About a third of youth (31\%) remain in residential care between three to twelve months, another $22.7 \%$ from 12 to 24 months. Those spending less than three months in short-term care make up $14.5 \%$ (MLPS, 2018). While data on unaccompanied minor refugees is not counted in the previous statistics, about one-quarter of them are in residential care programs, according to 2016 data (MLPS, 2018). 


\section{Major Current Issues, Strengths and Deficits}

Deinstitutionalization remains a policy priority and has further been strengthened by an explicit focus on prevention, not least through the national guidelines, which address interventions with vulnerable families and children (MLPS, 2017b) and reception in residential services (MLPS, 2017a), as well as through the P.I.P.P.I program [Program of Intervention for the Prevention of Institutionalization] (Santello, Colombini, Ius, \& Milani, 2018; Serbati, Santello, Colombini, \& Milani, 2016). The program aims to enhance resources in the family, in the local community, and for social professionals. Such efforts reflect the will to improve residential care and to build a national and common framework for all the Italian regions.

Identified challenges in residential care are the ambiguous classification of residential care units and uneven data collection. The latter is the responsibility of different regions and as such, national data tend to be incomplete or difficult to standardize (Corradini, 2017). Guidelines and standards put forth by the Central Government are often only partially followed by providers while regional standards tend to focus on administrative and bureaucratic aspects rather than the quality of programs (Licursi et al., 2013). Other problematic areas are high rates of personnel turnover, insufficient attention paid to the biological family, lack of individualization in the care of children and youth as well as a need for shared quality standards and greater integration in the protection system.

\section{Lithuania}

\section{Relevant Macro Context}

Lithuania inherited the Soviet model of social security, which is based on strong institutional care traditions. Since its Independence in 1990, the country has been reforming the protection of children's rights and has undergone radical changes in its economic and social systems. Numerous innovations were introduced in the field of family support and child protection services during the first decade of transition (1990-2000). However, after many attempts to deinstitutionalize the child welfare system, the country was still characterized by a high reliance on residential care and a large number of children under the age of three entering residential programs. The deinstitutionalization process stagnated due to the government's reluctance to take active steps in reforming residential care. However, the system of centralized residential institutions (including infant homes, special boarding schools, and special social care homes for persons with mental disabilities) mobilized to advocate for lasting reforms (Pivoriene, 2020; Rights of the Child in, 2012; Lithuania). As a result, rates of out-of-home care have dropped to a low of 3.1 per 1000 children (State Child Rights Protection and Adoption Service, 2020).

Since 2014, reforms in residential care have been guided by a strategic plan, which was conceptualized in two steps: (1) creation of the necessary conditions for the transformation (2014-2017), and (2) development of infrastructure in the regions (2017-2020/2023). While the process has been slower than anticipated, a 2020 evaluation of the first phase has been completed and has shown some positive results of the reforms, including a change from institutional programs to smaller group homes. 


\section{Residential Care System/Program Features}

Parallel to large reductions in out-of-home care, utilization rates of residential care have steadily dropped and were at $23.2 \%$ in 2019 . At present, children under the age of three can only be placed into residential care in exceptional cases (State Child Rights Protection and Adoption Service, 2020). Lithuania has 93 residential care programs, encompassing a mix of state, municipal and non-public residential care agencies. Since 2014, residential care agencies have been guided by licensing rules, which recommend a size of no more than eight children per program. Programs use different conceptual approaches and methods, but the primary approach can be described as community-based care. Current law requires the active involvement of family in residential care services; however, programs report challenges in the implementation process. Careleaver services are offered for youth up until the age of 21, and if they are still in school, until age 24 (Description of the Organization \& Quality of Accompanying Care Services, 2019).

\section{Residential Care Training and Personnel}

Residential care programs employ guardianship teams, which consist of residential care workers with a four-year bachelor's degree in social work, social work assistants who receive training courses as well as other professional staff, such as psychologists and social pedagogues. The recommended worker-youth ratio is two workers to eight children (Community Foster Care Home Description, 2020). The salary of an employee in the field of social services is about $77 \%$ of the average national salary.

\section{Characteristics of Children and Youth in Residential Care}

Slightly less than half of the youth in residential care are male (47\%). About two-thirds are ten and above, $22.6 \%$ are between four and nine, and $9.4 \%$ are younger than three years old. As stated earlier, the placement of infants can only occur under exceptional circumstances. The number of unaccompanied minor refugees in Lithuania is small and declining so services for this target group are not a national priority (Čerkauskienè, 2016; European Migration Network, 2018).

About three-quarters of the children in residential care programs enter due to neglect and child endangerment (State Child Rights Protection and Adoption Service, 2020). There is neither data regarding the average length of stay in residential care programs nor about the percentage of youth coming from single parent households. Mental health prevalence data on children in residential care is also lacking; however, children treated in psychiatric facilities are more often from residential care or other out-of-home care settings. According to a 2020 study (Lesinskienė et al., 2020), these children are characterized by repeated hospitalizations and the most common diagnosis involves behavioral and emotional disorders. There are three facilities in Lithuania specifically designated for children with various developmental and mental health disorders.

\section{Major Current Issues, Strengths and Deficits}

Statistical data show that planned quantitative outcomes of the reforms toward deinstitutionalization have been reached, however, some big challenges remain. For instance, an unintended consequence of the push to drastically reduce the number of children in 
institutions has been an undue focus on keeping children in their families or quickly reunifying them without adequate consideration of the best interests of the child (State Child Rights Protection and Adoption Service, 2020). There are also concerns about the competencies of residential care workers and the quality of care provided in residential care programs.

\section{Spain}

\section{Relevant Macro Context}

Historically, the Catholic Church and philanthropic organizations played a crucial role in child protection and residential institutions in Spain. Family-based placements launched very late (see Family Foster Care and Adoption Law of 1987), but around 1990, efforts were made by the national as well regional governments to promote family-based foster care and reduce residential placements, and reforms were implemented in order to close larger institutions that housed hundreds of children. Therefore, a transformation took place and small residential units emerged, which were more community- or family-oriented. Moreover, a shift towards regional authorities ("Autonomous Communities"), which were now responsible for child welfare and child protection, could be observed (Bravo \& Del Valle, 2009). After this transition, the number of adolescents with severe behavioral and emotional disorders increased and led to the development of specialized residential care programs. Unfortunately, many of these programs were not planned properly and did not fully consider the complex needs of children and youth. To date, foster parents host mainly younger children and those with fewer emotional problems, but the majority of foster care is kinship care (Del Valle et al., 2009). Strong family ties are believed to be the reason for the high ratio of kinship care and the slow implementation of the (nonrelative) foster care system (Del Valle et al., 2013; Kosher et al., 2018). Spanish law prioritizes the use of family-based care over residential care, especially for children under the age of six and always for children under the age of three. However, the essential role of residential care is recognized in child welfare law and quality standards were published by the national government (Del Valle, Bravo, Martinéz, \& Gonzaléz, 2012).

\section{Residential Care System/Program Features}

In $2018,40,828$ children and youth were reported to be in out-of-home care with an overall rate of 4.9 per 1,000 minors. Of available out-of-home care options, $52 \%$ were in residential care and $48 \%$ in foster care, with $64 \%$ being kinship care. Since about 2013, residential care rates have been increasing steadily, primarily due to the growing number of unaccompanied migrant children $^{4}$ (mostly from North Africa) entering programs (in 2018 the number was about $54 \%$ higher than in 2017).

Of the 1104 residential care programs across Spain, 60\% are small group homes, which generally house six to ten children each. However, there are about $17 \%$ of facilities that are considered 'large,' housing more than 20 minors. Programs for unaccompanied migrant children tend to fall into the category of 'large facilities.' Over 80 percent of residential

\footnotetext{
${ }^{4}$ In Spain, migrant children are not considered as refugees; they do not need to ask for asylum because they are looked after by the child welfare system as minors without family.
} 
care programs fall under the auspices of non-public agencies (private NGOs, denominational) whereas $20 \%$ are public.

Programs are primarily guided by social pedagogy concepts but also use systemic and behavioral approaches. Careleaver services have been developing steadily and, in 2015, were consolidated in legislation. These services are available for youth after the age of 16 until age 21 and beyond, depending on the region (there are no strict age limits). As in other countries, parent or family involvement is required by law but difficult to implement. Spain introduced national quality standards in 2012 (Del Valle et al., 2012). Additionally, regions may have their own procedures and processes for accreditation purposes.

\section{Residential Care Training and Personnel}

Residential care programs employ educational teams, which consist of social educators who are supported by a professional team of psychologists, pedagogues, and social workers. Social educators are professionals with a four-year bachelor's degree in social education. In some regions, technical education assistants with two years of vocational training in "social integration" or similar specialties also complement the team of social educators. In residential care programs, the worker to youth ratio is one to four but may be one to two or even one to one in therapeutic residential care. The average salary of a social educator is about $78 \%$ of the national median income.

\section{Characteristics of Children and Youth in Residential Care}

About two-thirds of youth in residential care are male and $63 \%$ fall into the 15 to 17 -year old age category. The percentage of children younger than seven years old is about six percent. About $55 \%$ of youth have a migration background, and most of them (88\%) are unaccompanied migrant children, almost all boys. About $62 \%$ of children and youth enter residential care for reasons of abuse and/or neglect. Regarding the length of time spent in residential care programs, a recent study indicated an average length of stay of 42.6 months (González-García et al., 2017; Martín, Gonzaléz-García, Del Valle, \& Bravo, 2020). The same study also documented elevated rates of mental health problems among residential care youth, with $61 \%$ meeting the threshold for clinical severity based on the Child Behavior Checklist and 49\% receiving psychological and/or psychiatric treatment. Eighty percent of the youth had at least one psychosocial risk factor (e.g., low socioeconomic status, substance abuse, mental health problems domestic violence, and criminality).

\section{Major Current Issues in Residential Care and Perceived Strengths and Deficits}

A particular challenge in the Spanish system is posed by the many unaccompanied minor migrants and the need to adapt existing concepts and methods for these youths. Identified deficits or challenges are the complex profiles of youth requiring new therapeutic residential care facilities and the difficulties of involving families of origin. Strengths include highly qualified staff, a successful implementation of deinstitutionalization policies with regard to the prohibition of residential care placement of children younger than six, the development of quality standards as well as recent policy changes supporting careleavers. 


\section{Comparative Analysis}

Following the case synthesis, a comparative analysis across cases was conducted to address each research question. Findings highlight areas of overlap as well as singularity.

\section{"How similar or different is residential care in its programming and features across the five countries?"}

Utilization rates in Context Germany and Finland stand out with relatively high out-ofhome care rates despite an explicit prevention and family-oriented focus in child welfare policy. Reasons for this dynamic are not entirely clear. In both countries, residential care is seen as a supportive service for families in distress, and voluntary placement is possible and encouraged. Additionally, the increasing complexity of psychosocial problems that families and youth face, which often prompt placements into residential care, have been raised as issues. Italy, Spain, and Lithuania have comparatively low out-of-home care rates with Italy and Spain sharing cultural values that are at the center of the so called "Mediterranean model" (Del Valle et al., 2013). Lithuania has pushed aggressively to deinstitutionalize and counteract the lasting effects of a previously highly institutionalized system. It has aimed to find solutions for children and youth other than out-of-home care and is increasingly relying on forms of kinship care as well as temporary or long-term foster care (Rimkus, 2016).

Residential care utilization always needs to be understood vis-à-vis the usage of familybased foster care while the usage of family-based foster care needs to be considered in relation to the availability of kinship care. Germany and Spain use residential care more often than foster care. In both Spain and Germany, much of the increase in residential care utilization during the past five years has been attributed to the arrival of unaccompanied migrant and refugee children and youth since the summer of 2015. In response to this crisis, new residential care facilities opened up. Frequently, these programs were larger ones to accommodate a greater number of youths. As the influx of these youths has slowed (as is the case in Germany), programs have again closed or have been reshaped to serve other target populations. Italy does not capture unaccompanied minors in its child welfare statistics, as such, its usage of residential care at about $50 \%$ (versus the use of family-based foster care) is comparably high.

The high rates in Germany can further be attributed to the fact that residential care, despite multiple scandals up until the present time, maintains a comparably positive image on the grounds of its long history, a rich tradition of pedagogy, and a professionalized workforce. In both Italy and Spain, efforts toward greater use of foster care have only been partially successful, and cultural constructions about the centrality of family may prevent greater acceptance of family-based foster care options in both Italy and Spain, thus contributing to higher residential care rates. Interesting in this regard are also the high rates of kinship care that make up a significant portion of foster care placements in Italy and Spain, signaling that family-based care may only find limited acceptance outside the related family. By contrast, formal kinship care delivered through the child welfare system remains a small part of the out-of-home care options in Germany or Finland.

Meanwhile, Finland and Lithuania have succeeded in reducing residential care significantly, yet, in different ways. Finland has developed an array of family-based foster care options consisting primarily of nonrelative foster care, professional family homes and some kinship care. Most of foster care in Lithuania is kinship care, yet as stated earlier, Lithuania has also expanded temporary and long-term nonrelative foster care options. 
Residential care program concepts and models By and large, residential care in the five countries involves a range of small(er) group homes, community-based or independent living arrangements with about six to ten children per program unit, with slight variations by country. With few exceptions, these settings bear little resemblance to the large institutions that are the focus of global deinstitutionalization efforts (Goldman et al., 2020). Milieubased pedagogical concepts focused on relationships and socialization processes dominate residential care practice in the five countries. Such concepts are not always well specified but stress reflexive, discursive, and individualized processes and methods. Behavioral management approaches and evidence-based methods more generally, are far less dominant than in Anglophone countries (e.g., James, 2015). However, there is some evidence that in countries like Finland, Germany and Spain, trauma-informed and mental health focused methods are slowly gaining in significance and are increasingly being integrated into 'usual' residential care. The emphasis on milieu-based approaches focused on creating a worthwhile living environment are in part necessitated by quite lengthy stays in residential care. Finland and Spain report average stays of 43 and 48 months, respectively, and about one-third of youth in Italy remain in residential care for two to four years or even longer.

In all five countries, the involvement of parents or families in residential care services is required by law, yet the gap between policy and practice remains large in this area. Similarly, careleaver services have been growing in significance in recent years, receiving support through legislation and additional funding. In all countries, supportive careleaver services can be received at a minimum until the age of 21 . Finland now guarantees services until the age of 25 , which is a unique feature. Germany, in rare cases, can extend services until the age of 27 .

\section{"How does the Training of Residential Care Workers Differ?"}

Residential care workers are frequently described as insufficiently trained, under-paid and prone to high turnover rates (Seti, 2008; Smith, 2017; Smith et al., 2019). Such observations are central to the critique leveled against residential care. While confirming that residential care workers' salaries remain below median incomes in the respective countries, this analysis, however, shows significant evidence of professionalization in residential care programs. Residential care staff usually work in teams that include university- as well as vocationally trained staff with degrees and training in social education, social work, social pedagogy, or nursing. While social work or technical education assistants with less training are part of most residential care teams, countries such as Finland require bettertrained workers to make up at least half of a team. Germany stands out in terms of having a residential care workforce, of which more than two-thirds are vocationally trained educators with three-and-a-half to five years of training. Spain and Italy also have a highly professionalized model for residential care. In contrast, residential care workers in Lithuania appear to be in earlier stages of professionalization.

Specific data on turnover rates in the respective countries was not available. Neither is data on whether a higher level of professionalization would be associated with better outcomes for children and youth. This remains an untested assumption that deserves to be investigated. Much remains to be learned about needed competencies and the optimal training of residential care workers, which seems so key to improving the quality of residential care (Eenshuistra, Harder \& Knorth, 2019). 


\section{"How do the Characteristics of Children and Youth in Residential Care Programs Compare?"}

The characteristics of residential care youth in the five studied countries generally resemble those reported for this population globally: predominately male (with the exception of Lithuania), adolescents, with high rates of mental health problems and other risk factors. While adolescents usually make up about two-thirds or more of youth in residential care, in this analysis, the percentage of younger children remains high in some of the countries when measured against policies and guidelines discouraging or even prohibiting the placement of infants and young children into residential care. Over one-third of children in Italian residential care are younger than age ten, of which $12.7 \%$ are younger than age two. Lithuania's numbers are similarly high, with a smaller percentage of children under the age of two or three, and over $40 \%$ of children in Finland are twelve and younger, with a reported $13.6 \%$ being younger than seven years old. One of Spain's current policy goals is the reduction of residential care placement for younger children and great progress has been made toward this goal. Germany's percentage of children under the age of six is the lowest in this country comparison.

Data on migration background is not universally captured, in part due to gaps in data collection but also (as in the case of Finland) because migration background is not considered to be a factor affecting access to services. Data on the rate of mental health problems and other risk factors are derived from research studies rather than administrative data; yet results largely converge with study findings from many other countries across the globe, confirming disproportionately high rates of emotional and behavioral problems among this group of children and youth (see Whittaker et al., 2015 for summaries on this issue across different countries).

Regarding primary reasons for entry into residential care, it is noteworthy that challenges to parental functioning such as exhaustion and difficulties in coping are frequently cited reasons for placement into residential care. Voluntary and youth-initiated placements also seem to be far more common than in countries where residential care is viewed primarily as a stop-gap option and ultimately an adverse outcome. This suggests that in these countries, residential care still serves as a way of preventing child abuse and neglect and a service or support to families in distress (Bellonci, Holmes, \& Whittaker, 2019).

\section{Discussion}

The current study provided evidence that residential care in the five countries remains-with some variation-an integral part of the continuum of services for children, and that in some countries it either maintains a comparatively positive image or is in fact the preferred outof-home care option. As such, a push toward the wholesale reduction of residential care, as has been occurring in countries like the United States or Australia, is not apparent, instead efforts are made in at least four of the five countries under study to improve the quality of residential care through the professionalization of its workforce, national quality standards, and improved implementation of program concepts and elements (e.g., careleaver services, family involvement, pedagogical milieu, protection concepts) that are believed to be core to the success of residential care. Beyond the findings already presented, several final points deserve noting.

Terminology in the field of residential care continues to be imprecise and confounding. Terms like institution, congregate care, residential programs, therapeutic residential care, 
group homes, etc. are frequently used interchangeably in the professional and academic literature. More often than not, studies aggregate diverse forms of residential care-in part due to small cell sizes-and insufficiently capture differences in size, target population, goals, or theoretical approach (Lee \& Barth, 2011). Further complicating matters is the fact that residential care is a cross-service system 'intervention,' serving children and youth who may have different starting or referral points (i.e., child welfare, juvenile justice, mental health, education). All of this has contributed to a 'broad-brushing' of residential care, which has been particularly detrimental in discussions on the developmental outcomes related to "institutions" and resultant policies (Goldman et al., 2020; Ijzendoorn et al., 2020; Stockholm Declaration, 2003). We opted for the generic umbrella term "residential care," knowing full well that this term is problematic in and of itself.

The international literature (in English) often describes residential care as a last resort placement that is solely justified when the severity of presenting problems is so grave that other lower-level options have either failed or are no longer available. This has led to residential care being called a "failure option" by some (e.g., Children's Commission, 2020) and has in some countries resulted in an increase in the clinical severity of youth in residential care (Duppong Hurley et al., 2009). Given the undoubtedly complex psychosocial needs of youth in residential care, which have been confirmed in this analysis, all residential care should indeed have sound pedagogical and/or therapeutic goals (Whittaker et al., 2016). Nonetheless, residential care should not be de facto inpatient psychiatric treatment, merely focused on the reduction of clinically significant symptoms. The countries captured in this analysis, by-and-large, emphasize the pedagogical potential of residential care and conceptualize it as a setting and milieu where children live and learn. This demands concepts and models capable of supporting such objectives (Anglin, 2004; Holmes et al., 2018).

The analysis highlighted the complexities of balancing deinstitutionalization efforts with the advancement and availability of family- and community-based alternatives. Our analysis indicated significant barriers to the advancement of family foster care based in part on cultural constructions about the role of the family. Cultural attitudes, by definition, tend to be deeply engrained and would have to be addressed mindfully and sensibly. Restricting the role of residential care without concomitant attention paid to the building up of familybased options is destined to create adverse unintended consequences, as already apparent in countries such as Australia (e.g., Ainsworth \& Hansen, 2005).

\section{Limitations and Direction for Future Studies}

This analysis encountered all of the problems that are inherent to case-study designs (e.g., Gustafsson, 2017) as well as cross-country comparisons (e.g., Ezell et al., 2011; Freymond $\&$ Cameron, 2006): The study was limited to five countries on one continent and collected data at one point in time; it produced a lot of data but only a select range of salient variables could be highlighted, and analysis was restricted to key considerations that are relevant in the context of deinstitutionalization efforts. Future efforts should, for instance, expand analysis to compare experiences, concepts, and outcomes of subgroups of youth in residential care, such as LGBTQA+youth. Additionally, the training and level of professionalization of residential care workers and the association of these variables to outcomes are particularly ripe for further inquiry.

Data collection was in part uneven due to unavailable or missing data, differences in terminology and denominators, and significant in-country variability. While this poses a 
challenge for the comparability and validity of data, measures were taken to resolve issues and consider them in the interpretation of findings. The difficulties in finding and harmonizing data underscore the potentially important role of administrative data, which in many countries are not yet systematically collected on residential care. This analysis was also limited to a cross-case synthesis. Future efforts should expand analysis toward the development of a typology along dimensions addressed here. This would allow the testing of theoretical predictions about "types" of residential care within country contexts. Despite these limitations, findings from this analysis contribute to a fuller and perhaps corrective understanding of residential care, challenging the "residential-care-as-a-last-resort-only" rhetoric that is currently dominating the professional and academic discourse on residential care.

Funding Open Access funding enabled and organized by Projekt DEAL. This research was supported by the Erasmus+program; project number: 2018-1-FI01-KA203-047242.

Open Access This article is licensed under a Creative Commons Attribution 4.0 International License, which permits use, sharing, adaptation, distribution and reproduction in any medium or format, as long as you give appropriate credit to the original author(s) and the source, provide a link to the Creative Commons licence, and indicate if changes were made. The images or other third party material in this article are included in the article's Creative Commons licence, unless indicated otherwise in a credit line to the material. If material is not included in the article's Creative Commons licence and your intended use is not permitted by statutory regulation or exceeds the permitted use, you will need to obtain permission directly from the copyright holder. To view a copy of this licence, visit http://creativecommons.org/licenses/by/4.0/.

\section{References}

Ainsworth, F., \& Hansen, P. (2005). A dream come true - no more residential care. A corrective note. International Journal of Social Welfare, 14(3), 195-199.

Ainsworth, F., \& Thoburn, J. (2014). An exploration of the differential usage of residential childcare across national boundaries. International Journal of Social Welfare, 23(1), 16-24. https://doi.org/10.1111/ ijsw. 12025

AKJ (2018). 20 Jahre KomDat Jugendhilfe. Kommentierte Daten der Kinder- \& Jugendhilfe, 1, 1-36. Available at: http://www.akjstat.tu-dortmund.de/fileadmin/user_upload/AKJStat/Komdat/2018_Heft1_ KomDat.pdf

Anglin, J. (2004). Creating "well-functioning" residential care and defining its place in a system of care. Child \& Youth Care Forum, 33(3), 175-192. https://doi.org/10.1023/B:CCAR.0000029689.70611.0f

Bellonci, C., Holmes, L., \& Whittaker, J. (2019). Re-thinking therapeutic residential care (TRC) as a preventive service: Examining developments in the US and England. Residential Treatment for Children \& Youth. https://doi.org/10.1080/0886571X.2018.1536495

Berman, H., Mulcahy, G. A., Forchuk, C., Edmunds, K. A., Haldenby, A., \& Lopez, R. (2009). Uprooted and displaced: A critical narrative study of homeless, Aboriginal, and newcomer girls in Canada. Issues in Mental Health Nursing, 30(7), 418-430. https://doi.org/10.1080/0161284080262447

BGW (2018). Kinder- und Jugendhilfe in Deutschland. Ein Datenbericht 2018 [Child- and Youth Care in Germany. A data report 2018.]. Hamburg, Germany: BGW.

BMFSFJ (Federal Ministry for Family Affairs, Senior Citizens, Women and Youth) (2020). 16. Kinder und Jugendbericht $\left[16^{\text {th }}\right.$ Child and Youth Report]. Berlin, Germany: BMFSFJ.

Bravo, A., \& Del Valle, J. F. (2009). Crisis and review of residential child care Its role in child protection. Papeles Del Psicólogo, 30(1), 42-52.

Cameron, C., Hollingworth, K., Schoon, I., van Santen, E., Schröer, W., Ristikari, T., Heino, T., \& Pekkarinen, E. (2018). Care leavers in early adulthood: How do they fare in Britain, Finland and Germany? Children and Youth Services Review, 87, 163-172. https://doi.org/10.1016/j.childyouth.2018.02.031

Canali, C., Maurizio, R., \& Vecchiato, T. (2016). Foster care: motivations and challenges for foster families. Social Work \& Society, 14(2), 1-14. http://nbn-resolving.de/urn:nbn:de:hbz:464-sws-1072

Carrà, E. (2014). Residential care: An effective response to out-of-home children and young people? Child \& Family Social Work, 19, 253-262. https://doi.org/10.1111/cfs.12020 
Canali, C., \& Vecchiato, T. (Eds.) (2013). Foster care in Europe: what do we know about outcomes and evidence? Padova, Italy: Fondazione Zancan.

Čerkauskienė, R. (2016). Nelydimų nepilnamečių užsieniečių situacijos apžvalga ir teisnis reglamentavimas lietuvoj [Overview of the situation concerning unaccompanied minor aliens and legal regulation in Lithuania]. In Visuomenès saugumas ir viešoji tvarka. Public security and public order (16) (pp. 39-50). Vilnius, Lithuania: Mykolo Romerio Universitetas. Available at: https://repository.mruni.eu/ bitstream/handle/007/15016/\%C4\%8Cerkauskien\%C4\%97.pdf?sequence=1\&isAllowed=y

Chadwick Center and Chapin Hall (2016). Using evidence to accelerate the safe and effective reduction of congregate care for youth involved with child welfare. San Diego, CA \& Chicago, IL: Collaborating at the Intersection of Research and Policy.

Child Welfare Information Gateway (n.d.). Group and residential care. Children's Bureau/US Department of Health and Human Services. Available at: https://www.childwelfare.gov/topics/outofhome/groupresidential-care/

Children's Commission (2020). The children who no-one knows what to do with. Briefing. Children's Commission for England. Available at: https://www.childrenscommissioner.gov.uk/wp-content/uploads/ 2020/11/cco-the-children-who-no-one-knows-what-to-do-with.pdf

Community Foster Care Home Description (2020). Order of the Minister of Social Security and Labor of the Republic of Lithuania. Available at: https://eseimas.lrs.lt/portal/legalAct/lt/TAP/d23e33c079 5e11eaa38ed97835ec4df6? positionInSearchResults=15\&searchModelUUID=7e2cdae3-d898-43b2ad66-e9fbfd662952

Corradini, F. (2017). Foster care and residential care: What factors affect the type of placement of children An Italian study. Relational Social Work, 1(2), 71-91.

Creswell, J. W., \& Poth, C. N. (2017). Qualitative inquiry and research design: choosing among five approaches (4th ed.). Sage Publishing.

Daly, D. L., Huefner, J. C., Bender, K. R., Davis, J. L., Whittaker, J. K., \& Thompson, R. W. (2018). Quality care in therapeutic residential programs: definition, evidence for effectiveness, and quality standards. Residential Treatment for Children \& Youth, 35(3), 242-262.

Del Valle, J. F., Canali, C., Bravo, A., \& Vecchiato, T. (2013). Child protection in Italy and Spain: Influence of the family supported society. Psychosocial Intervention, 22, 227-237. https://doi.org/10.5093/ in $2013 \mathrm{a} 26$

Del Valle, J. F., Bravo, A., Martinéz, M. H, \& González, I. S. (2012). Estándares de calidad en acogimiento residencial especializado. EQUAR-E [Quality standards in foster care/specialized residential. EQUAR-E.] Ministerio de Sanidad, Spain: Servicios e Igualdad.

Del Valle, J. F., López, M., Montserrat, C., \& Bravo, A. (2009). Twenty years of foster care in Spain: Profiles, patterns and outcomes. Children and Youth Services Review, 31, 847-853. https://doi.org/10. 1016/j.childyouth.2009.03.007

Description of the Organization and Quality of Accompanying Care Services (2019). Project of institutional care Reform. Available at: https://www.pertvarka.lt/wp-content/uploads/2019/06/PALYDIMTHSIOSGLOBOS-PASLAUGU-ORGANIZAVIMO-IR-KOKYBES-PRIEZIUROS-APRASAS.pdf

Die Zeit (n.d.). Was Sozialarbeiter und Sozialpädagogen verdienen: Gehalt und Einflussfaktoren [What social workers and social pedagogues earn: Income and predictors]. Available at: https://www.acade mics.de/ratgeber/sozialarbeiter-gehalt.

Dozier, M., Kaufman, J., Kobak, R., O'Connor, T. G., Sagi-Schwartz, A., Scott, S., \& Zeanah, C. H. (2014). Consensus statement on group care for children and adolescents: A statement of policy of the American Orthopsychiatric Association. American Journal of Orthopsychiatry, 84(3), 219-225.

Ducci, V. (2003). Beyond the orphanage: the process of deinstitutionalizing children in Italy. In UNICEF Innocenti Research Centre (Eds.), Children in institutions: The beginning of the end (pp. 1-24). Florence, Italy: UNICEF Innocenti Research Centre.

Duppong Hurley, K., Trout, A., Chmelka, M. B., Burns, B. J., Epstein, M. H., Thompson, R. W., \& Daly, D. L. (2009). The changing mental health needs of youth admitted to residential group home care. Comparing mental health status at admission in 1995 and 2004. Journal of Emotional and Behavioral Disorders, 17, 164-176. https://doi.org/10.1177/1063426608330791

Eenshuistra, A., Harder, A. T., \& Knorth, E. J. (2019). One size does not fit all: A systematic review of training outcomes on residential youth care of professionals' skills. Children and Youth Services Review, 103, 135-147.

European Migration Network (2018). Annual report on migration and asylum 2017. European Commission. Available at: https://ec.europa.eu/home-affairs/sites/homeaffairs/files/00_annual_report_on_migra tion_2017_highres_en.pdf 
Ezell, M., Spath, R., Zeira, A., Canali, C., Fernandez, E., Thoburn, J., \& Vecchiato, T. (2011). An international classification system for child welfare programs. Children and Youth Services Review, 33, 1847-1854. https://doi.org/10.1016/j.childyouth.2011.05.003

Farmer, E. M. Z., Murray, L. M., Ballentine, K., Rauktis, M. E., \& Burns, B. J. (2017). Would we know it if we saw it? Assessing quality of care in group homes for youth. Journal of Emotional and Behavioral Disorders, 25(19), 28-36. https://doi.org/10.1177/1063426616687363

Fendrich, S., Pothmann, J., \& Tabel, A. (2018). Monitor - Hilfen zur Erziehung 2018 [Monitor - Supportive Services for Education/Upbringing 2018]. Dortmund, Germany: Arbeitsstelle Kinder- und Jugendhilfestatistik.

Flyvbjerg, B. (2006). Five misunderstandings about case-study research. Qualitative Inquiry, 12(2), 219245. https://doi.org/10.1177/1077800405284363

Formenti, L., \& Rigamonti, A. (2020). Systemic reflexivity in residential child care: A pedagogical frame to empower professional competence. International Journal of Child, Youth \& Family Studies, 11(4.2), $115-139$.

Forsberg, H., \& Kröger, T. (2010). Introduction. In H. Forsberg \& T. Kröger (Eds.), Social work and child welfare politics. Through Nordic lenses (pp. 1-9). Bristol, UK: The Policy Press.

Forsell, M. (2019). Kuuden suurimman kaupungin lastensuojelun palvelujen ja kustannusten vertailu vuonna 2018. [Comparison of child welfare services and costs in the six largest cities in 2018]. Kuusikko-työryhmä. Kuusikko-työryhmänjulkaisusarja 2/2019. Available at: https://www.hel.fi/hel2/ tietokeskus/julkaisut/pdf/19_06_03_Kuusikko_Lastensuojelu_2018.pdf

Francis, J., Kendrick, A., \& Pösö, T. (2007). On the margin? Residential child care in Scotland and Finland. European Journal of Social Work, 10(3), 337-352. https://doi.org/10.1080/13691450701356614

Freymond, N., \& Cameron, G. (2006). Towards positive systems of child and family welfare: International comparisons of child protection, family service, and community caring systems. University of Toronto Press. https://doi.org/10.3138/9781442682726

Gahleitner, S. (2012). Traumapädagogik und psychosoziale Traumarbeit: Modeerscheinung oder Notwendigkeit? [Trauma-informed practice and psychosocial trauma work in residential care for children and adolescents - passing fad or absolute imperative? Trauma \& Gewalt, 6(3), 206-217.

Goldman, P.S., Bakermans-Kranenburg, M.J., Bradford, B., Christopoulos, A., Lim Ah Ken, P., Cuthbert, C.,Sonuga-Barke, E.J.S. (2020). Institutionalisation and deinstitutionalisation of children 2: Policy and practice recommendations for global, national, and local actors. Lancet Child and Adolescent Health, online. https://doi.org/10.1016/S2352-4642(20)30060-2

González-García, C., Bravo, A., Arruabarrena, I., Martín, E., Santos, I., \& Del Valle, J. F. (2017). Emotional and behavioral problems of children in residential care: Screening detection and referrals to mental health services. Children and Youth Services Review, 73, 100-106. https://doi.org/10.1016/j.child youth.2016.12.011

Grietens, H. (2015). A European perspective on the context and content for social pedagogy in therapeutic residential care. In J.K. Whittaker, J.F. Del Valle, \& L. Holmes (Eds.), Therapeutic residential care for children and youth. Developing evidence-based international practice (pp. 288-300). London, UK: Jessica Kingsley Publishers.

Günder, R., \& Nowacki, K. (2020). Praxis und Methoden der Heimerziehung (6th ed.) [Practice and methods of residential care]. Freiburg, Germany: Lambertus.

Gustafsson, J. (2017). Single case studies vs. multiple case studies: A comparative study. https://www.divaportal.org/smash/get/diva2:1064378/FULLTEXT01.pdf

Gutterswijk, R. V., Kuiper, C. H. Z., Lautan, N., Kunst, E. G., van der Horst, F. C. P., Stams, G. J., \& Prinyie, P. (2020). The outcome of non-residential youth care compared to residential youth care: A multilevel meta-analysis. Children and Youth Services Review, 113, 104950. https://doi.org/10.1016/j. childyouth.2020.104950

Harder, A. T., Zeller, M., López, M., Köngeter, S., \& Knorth, E. J. (2013). Different sizes, similar challenges: Out of home care for youth in Germany and the Netherlands. Psychosocial Interventions, 22, 203-213. https://doi.org/10.5093/in2013a24

Heale, R., \& Twycross, A. (2018). What is a case study. Evidence Based Nursing, 21(1), 7-8.

Heino, T., Hyry, S., Ikäheimo, S., Kuronen, M \& Rajala, R. (2016). Lasten kodin ulkopuolelle sijoittamisen syyt, taustat, palvelut ja kustannukset. HuosTa-hankkeen (2014-2015) päätulokset. [Reasons, backgrounds, services and costs concerning the placing of children outside the home. Main results from the HuosTa Project (2014-2015)]. Helsinki: National Institute for Health and Welfare (THL). Report 3/2016. Available at: https://www.julkari.fi/bitstream/handle/10024/130536/URN_ISBN_978-952302-644-5.pdf? sequence $=1 \&$ isAllowed $=y$

Landesjugendhilfeausschuss Hessen (2014). Richtlinien für (teil-)stationäre Einrichtungen in Hessen, die gemäß \& 45 Achtes Buch Sozialgesetzbuch (SGB VIII) - Kinder- und Jugendhilfe - einer 
Betriebserlaubnis bedürfen [Guidelines for (partial) out-of-home care settings in Hessia, which according to $\S 45$. Available online: https://soziales.hessen.de/sites/default/files/media/hsm/heimr ichtlinien_24.2.2014.pdf.

Hestbæk, A.-D., Höjer, I., Pösö, T., \& Skivenes, M. (2020). Child welfare removal of infants: Exploring policies and principles for decision-making in Nordic countries. Children and Youth Services Review, 108, 104572. https://doi.org/10.1016/j.childyouth.2019.104572

Hoikkala, S., \& Kemppainen, M. (2015). Running away from children's residential care: The Finnish case. International Journal of Child, Youth \& Family Studies, 6(3), 466-477.

Holmes, L., Connolly, C., Mortimer, E., \& Hevesi, R. (2018). Residential group care as a last resort: Challenging the rhetoric. Residential Treatment for Children \& Youth, 35(3), 209-224. https://doi.org/10. 1080/0886571X.2018.1455562

Huynh, H. V., Limber, S. P., Gray, C. L., Thompson, M. P., Wasonga, A. I., Vann, V., \& Whetten, K. (2019). Factors affecting the psychosocial well-being of orphan and separated children in five low- and middle-income countries: Which is more important, quality of care or care setting? PLoS ONE, 14(6), e0218100. https://doi.org/10.1371/journal.pone.0218100

Ijzendoorn, M.H. v., Bakermans-Kranenburg, M.J., Duschinsky, R., Fox, N.A., Goldman, P.S., Gunnar, M.R., Sonuga-Barke, E.J.S. (2020). Institutionalisation and deinstitutionalisation of children 1: a systematic and integrative review of evidence regarding effects on development. Lancet Psychiatry, online (June 23). https://doi.org/10.1016/S2215-0366(19)30399-2.

Islam, T. \& Fulcher, L. (Eds.) (2018). Residential child and youth care in a developing world. Cape Town, South Africa: The CYC-Net Press. Available at: https://www.press.cycnet.org/samples/Middle\% 20East\%20and\%20Asia_Perspectives-ebook.pdf

James, S. (2015). Evidence-based practice in therapeutic residential care. In J. K. Whittaker, J. F. del Valle, \& L. Holmes (Eds.), Therapeutic residential care for children and youth developing evidence-based international practice (pp. 142-155). Jessica Kingsley Publishers.

Janze, N., \& Pothmann, J. (2003). Modernisierung der Heimerziehung: Mythos oder Realität? [Modernization of residential care: Myth or reality?] In N. Struck, M. Galuske, \& W. Thole (Eds.), Reform der Heimerziehung. Eine Bilanz [Reform of residential care. A summary] (pp.101-121). Wiesbaden, Germany: VS Verlag für Sozialwissenschaften. https://doi.org/10.1007/978-3-322-89888-3_7

Kananoja, A., \& Ruuskanen, K. (2019). Selvityshenkilön ehdotukset lastensuojelun toimintaedellytysten ja laadun parantamiseksi [Investigator's suggestions for improving the conditions and quality of child protection]. Reports of the Ministry of Social Affairs and Health, 4. Ministry of Social Affairs and Health. Available at: https://julkaisut.valtioneuvosto.fi/bitstream/handle/10024/161379/Selvityshe nkilon_edellytykset_lastensuojelun.pdf?sequence $=4 \&$ isAllowed $=\mathrm{y}$

Kappler, S., Hornfeck, F., Pooch, M.T., Kindler, H., \& Tremel, I. (2019). Kinder und Jugendliche besser schützen. Der Anfang ist gemacht. Abschlussbericht des Monitorings zum Stand der Prävention sexualisierter Gewalt an Kindern und Jugendlichen in Deutschland (2015-2018) [Protecting children and youth better. The beginning is made. Final monitoring report about the status of preventing the sexualized violence of children and youth in Germany (2015-2018)]. Munich, Germany: DJI.

Kiuru, K-E., \& Metteri, A. (2014). Miten lastensuojelun ja nuorisopsykiatrian välinen raja rakentuu palvelujärjestelmässä? [How the boundary between child protection and adolescent psychiatry is constructed in the service system?] Sosiaalilääketieteellinen Aikakauslehti, 51, 146-160.

Kosher, H., Montserrat, C., Attar-Schwartz, S., Casa, F., \& Zeira, A. (2018). Out-of-home care for children at-risk in Israel and in Spain: Current lessons and future challenges. Psychosocial Interventions, 27(1), 12-21. https://doi.org/10.5093/pi2018a4

Krause, H.U. (2019). Beteiligung als umfassende Kultur in den Hilfen zur Erziehung.[Participation as encompassing culture in child welfare services]. Frankfurt, Germany: IGFH.

Kuoppala, T., Forsell, M., \& Säkkinen, S. (2019). Lastensuojelutilasto 2018. THL - Tilastorportti, 23. Available at: https://www.julkari.fi/bitstream/handle/10024/138211/Tr23_19_LASU.pdf?seque nce $=5$

Laakso, R. (2009). Arjen rutiinit ja yllätykset - Etnografia lastenkotityöstä. [Everyday routines and surprises - an ethnographic study of residential care work]. Tampere: Tampere University. Available at: https://trepo.tuni.fi/bitstream/handle/10024/66529/978-951-44-7808-6.pdf?sequence=1

Lahtinen, J., \& Pekkarinen, E. (2020). Yhteensointuvia ja epävireisiä kohtaamisia lastensuojelussa. Tutkimus osallisuudesta ja lastenkotien retkistä. [Harmonic and discordant encounters in child welfare. A study of inclusion and field trips for children's homes]. Yhteiskuntapolitiikka, 85(2), 157-167. Available at: http://urn.fi/URN:NBN:fi-fe2020040110041

Lee, B.R. (2020). Residential programs. Opportunities and challenges in the 21 st-century treatment environment. In Thomas W. Farmer, M.A. Conroy, E.M.Z. Farmer, \& K.S. Sutherland 
(Eds.), Handbook of research on emotional and behavioral disorders (pp. 306-320). New York: Routledge.

Lee, B. R., \& Barth, R. P. (2011). Defining group care programs: An index of reporting standards. Child \& Youth Care Forum, 40, 253-266. https://doi.org/10.1007/s10566-011-9143-9

Lee, E., Mishna, F., \& Brennenstuhl, S. (2010). How to critically evaluate case studies in social work. Research on Social Work Practice, 20, 682-689. https://doi.org/10.1177/1049731509347864

Lesinskienè, S., Dervinytė Bongarzoni, A., Istomina Fakulina, N., Zuoua, R., Vasiliauskienė, \& Jackevičienė, L. (2020). Psichikos sveikatos sutrikimų turinčių vaikų šeimths situacijos tyrimas. Health Sciences in Eastern Europe, 30(1), 65-69

Licursi, S., Macello, G., \& Pascuzzi, E. (2013). Children in need in the south of Italy: Features and distortions in the deinstitutionalization of care. Children \& Society, 27, 337-349. https://doi.org/10. 1111/j.1099-0860.2011.00416.x

Malja, M., Puustinen-Korhonen, A., Petrelius, P., \& Eriksson, P. (Eds.) (2020). Quality recommendations for child welfare. Publications of the Ministry of Social Affairs and Health, 28. Available at: https://julkaisut.valtioneuvosto.fi/bitstream/handle/10024/162454/STM_2020_28_J.pdf?seque nce $=1 \&$ isAllowed $=\mathrm{y}$

Martín, E., González-García, C., Del Valle, J. F., \& Bravo, A. (2020). Detection of behavioral and emotional disorders in residential child care: Using a multi-informant approach. Children and Youth Services Review, 108, 1-6. https://doi.org/10.1016/j.childyouth.2019.104588

Merchel, J. (2020). Kriterien für eine ,gute” Heimerziehung [Criteria for "good“ residential care]. Gütersloh, Germany: Bertelsmann Stiftung. Available at: https://www.bertelsmann-stiftung.de/ fileadmin/files/BSt/Publikationen/GrauePublikationen/KeKiz_WB8blau_Heimerziehung.pdf

Ministry of Work and Social Policies [MLPS] (2017b). National guidelines. Intervention with children and families in situation of vulnerability. Promotion of positive parenthood. Available at: https:// www.lavoro.gov.it/temi-e-priorita/infanzia-e-adolescenza/focus-on/sostegno-alla-genitorialita/ Documents/Linee-guida-sostegno-famiglie-vulnerabili-2017.pdf

Ministry of Work and Social Policies [MLPS] (2017a). National guidelines for reception in residential services for minors. Available at: https://www.lavoro.gov.it/temi-e-priorita/infanzia-e-adole scenza/focus-on/minorenni-fuori-famiglia/Documents/Linee-guida-accoglienza-minorenni.pdf

Ministry of Work and Social Policies [MLPS] (2018). Affidamenti familiari e collocamenti in comunità al 31 dicembre 2016. Available at: https://www.minori.gov.it/en/minori/affidamenti-familiari-ecollocamenti-comunita-al-31122016-indagine-campionaria

Moore, T., McArthur, M., Death, J., Tilbury, C., \& Roche, S. (2018). Sticking with us through it all: The importance of trustworthy relationships for children and young people in residential care. Children and Youth Services Review, 84, 68-75. https://doi.org/10.1016/j.childyouth.2017.10.043

Palareti, L., Berti, C., \& Emiliani, F. (2012). Comunità residenziali e lavoro di rete nella prospettiva ecologica dello Sviluppo [Residential communities and networking in the ecological perspective of development]. Psicologia Clinica Dello Sviluppo, 1, 71-95.

Pivoriene, J. (2020). Deinstitutionalization of the child care system in Lithuania. International Journal of Child, Youth \& Family Studies, 11(41), 121-131.

Porko, P., Heino, T., \& Eriksson, P. (2018). Selvitys yksityisistä lastensuojelun yksiköistä [Survey on private residential care units]. Terveyden ja hyvinvoinnin laitos (THL). Työpaperi 21/2018. Available at: http://urn.fi/URN:ISBN:978-952-343-131-7

Puustinen-Korhonen, A. (2018). Child protection municipal survey. Association of Finnish Local and Regional Authorities.

Rights of the Child in Lithuania (2012). NGO Report for the UN Committee on the Rights of the Child on the 3rd and 4th Periodic Reports by the Government of Lithuania. Available at: https://tbint ernet.ohchr.org/Treaties/CRC/Shared\%20Documents/LTU/INT_CRC_NGO_LTU_14046_E.pdf

Rimkus, V. (2016). Socialinès pagalbos poreikis šeimoje globojamam vaikui ir jo globejjui: globejjų požiūrių analizè / Social work support for foster carers and fostered children: analysis of foster carers" perspective. TILTAI, 1, 105-131. Available at: https://core.ac.uk/download/pdf/23317 9128.pdf

Santello, F., Colombini, S., Ius, M., \& Milani, P. (2018). Impact evaluation of the P.I.P.P.I programme: a first application of counterfactual analysis. Innovative Infotechnologies for Science, Business and Education, 1(24), 13-21.

Schmid, M., Goldbeck, L., Nuetzel, J., \& Fegert, J. (2008). Prevalence of mental disorders among adolescents in German youth welfare institutions. Child and Adolescent Psychiatry and Mental Health, 2(2), 1-8. https://doi.org/10.1186/1753-2000-2-2 
Serbati, S., Santello, F., Colombini, S., \& Milani, P. (2016). Challenges for the evaluation of the P.I.P.P.I. programme of intervention for prevention of institutionalisation: between and experimental pathways. Interdisciplinary Journal of Family Studies, 21(2), 1-24.

Seti, C. L. (2008). Causes and treatment of burnout in residential child care workers: A review of the research. Residential Treatment for Children \& Youth, 24(3), 197-229.

Smith, Y. (2017). "Sense" and sensitivity: Informal apprenticeship among youth care workers in a residential treatment center for children. Child \& Family Social Work, 22(3), 1330-1337. https://doi. org/10.1111/cfs. 12350

Smith, Y., Colletta, L., \& Bender, A. E. (2019). Moral people or moral projects? Worker altruism in youth residential treatment. Culture, Medicine and Psychiatry, 43(1), 25-55. https://doi.org/10. 1007/s11013-018-9594-7

State Child Rights Protection and Adoption Service (2020). Annual Report 2019. Vilnius. Available at:https://vaikoteises.lt/media/file/2019/2019\%20m.\%20veiklos\%20ataskaita\%203.pdf

Statistisches Bundesamt (2018). Statistiken der Kinder- und Jugendhilfe - Erzieherische Hilfe, Eingliederungshilfe, Hilfe für junge Volljährige 2018; Ausgaben und Einnahmen 2018, Einrichtungen und tätige Personen 2018; Datenzusammenstellung und Berechnungen der Arbeitsstelle Kinder- und Jugendhilfestatistik [Child and youth welfare statistics]. Available at: http://hzemonitor.akjstat.tu-dortmund.de/ steckbriefe-der-hilfearten/heimerziehung-34-sgb-viii

Stockholm Declaration on Children and Residential Care (2003). Children and Residential Care Conference, May 12-15. Available at: https://resourcecentre.savethechildren.net/library/stockholm-decla ration-children-and-residential-care-12-15-may-2003

Timonen-Kallio, E., \& Hämäläinen, J. (2019). Social pedagogy-informed residential child care. International Journal of Social Pedagogy, 7(1), 1-14.

Timonen-Kallio, E., Hämäläinen, J., \& Laukkanen, E. (2017). Interprofessional collaboration in Finnish residential child care: Challenges in incorporating and sharing expertise between the child protection and health care systems. Child Care in Practice, 23(4), 389-403.

Valvira (2012). Lastensuojelun ympärivuorokautinen hoito ja kasvatus, valtakunnallinen valvontaohjelma 2012-2014. [24-hour care and education of child protection, nationwide monitoring program]. Sosiaali- ja terveysalan lupa- ja valvontavirasto.

Whittaker, J. K., Del Valle, J. F., \& Holmes, L. (Eds.). (2015). Therapeutic residential care for children and youth. Jessica Kingsley Publishers.

Whittaker, J., Holmes, L., del Valle, J. F., Ainsworth, F., Andreassen, T., Anglin, J., \& Zeira, A. (2016). Therapeutic residential care for children and youth: A consensus statement of the international work group on therapeutic residential care. Residential Treatment for Children and Youth, 33(2), 89-106. https://doi.org/10.1080/0886571X.2016.1215755

Working Group to Reform After-Care (2019). Report of the Working group to reform after-care. Reports and Memorandums of the Ministry of Social Affairs and Health, 43. Ministry Social Affairs and Health. Available at: https://julkaisut.valtioneuvosto.fi/bitstream/handle/10024/ 161637/STM_Rap_2019_43__Lastensuojelun_jalkihuollon_uudistamistyoryhman_loppuraportti. pdf? sequence $=1 \&$ is Allowed $=\mathrm{y}$

Yin, R. K. (2018). Case study research and applications. Design and methods. Sage Publications.

Zukunftsforum Heimerziehung. (2021). Zukunftsimpulse für die Heimerziehung. Eine nachhaltige Infrastruktur mit jungen Menschen gestalten! [Impulses for the future for residential care. Building a sustainable infrastructure with young people]. Frankfurt, Germany: Internationale Gesellschaft für Erzieherische Hilfen.

Publisher's Note Springer Nature remains neutral with regard to jurisdictional claims in published maps and institutional affiliations. 


\section{Authors and Affiliations}

Sigrid James ${ }^{1}$ (D) . Lucas Wilczek ${ }^{1} \cdot$ Juri Kilian $^{1} \cdot$ Eeva Timonen-Kallio ${ }^{2} \cdot$ Amaia Bravo $^{3}$. Jorge F. del Valle ${ }^{3}$. Laura Formenti ${ }^{4}$. Alina Petrauskiene ${ }^{5}$. Jolanta Pivoriene ${ }^{5}$. Alessandra Rigamonti ${ }^{4}$

1 Department of Social Work and Social Welfare, University of Kassel, Kassel, Germany

2 Faculty of Health and Well-Being, Turku University of Applied Sciences, Turku, Finland

3 Faculty of Psychology, University of Oviedo, Oviedo, Spain

4 Department of Human Sciences for Education, University of Milano Bicocca, Milan, Italy

5 Institute of Educational Sciences and Social Work, Mykolas Romeris University, Vilnius, Lithuania 